\title{
THE CONSTITUTION OF PHYSICIANS' POWER: A THEORETICAL FRAMEWORK FOR COMPARATIVE ANALYSIS
}

\author{
Luis Duran-Arenas ${ }^{1}$ and Michael KenNeDY ${ }^{2}$ \\ 'Advanced Educational Program in Health Services Organization and Management, National Institute \\ of Public Health of Mexico, Francisco de P. Miranda 177, Col. Merced Gomez, Mexico, D.F. 01600 and \\ ${ }^{2}$ Department of Sociology, The University of Michigan, 3012 LS \& A, Ann Arbor, MI 48109-1302, U.S.A.
}

\begin{abstract}
Drawing on literatures documenting the experience of physicians in both European and American societies, a new theoretical framework for explaining variations in the professional power of physicians is provided. Most studies of professions have used professional organization as the principal explanatory variable, with state policy and the organization of civil society as secondary mediating factors. Our approach instead treats strategies of state power and forms of civil society as central features shaping the ability of the profession to exert power. Such a three-dimensional approach not only allows us to make more powerful classifications explaining contemporary differences, but also allows us to trace historical shifts and anticipate alternative futures in professional power. For example, in those societies where the state's intervention is limited and civil society is pluralistic, professional power is potentially greatest. But increasing state power does not necessarily reduce professional power. Where the state is most powerful and organizes all groups in civil society, professionals and society can be united in common struggle against the state. In response to that, it is likely that such centralized states will opt for corporatist solutions to maximize the internal differentiation of society and pit those once allied against one another, and preclude the oganization of powerful autonomous interest groups.
\end{abstract}

Key words-professionalization, professional power, state intervention, comparative analysis

How is the professional power" of physicians developed in different kinds of societies? Are the forms taken to limit or to augment professional power different in societies with contrasting political economies, as in state capitalist Mexico and state socialist Poland? Or is professional power being limited everywhere as a consequence of some general evolutionary trend?

Frenk and Donabedian suggest that state intervention in health care has increased over time, although along different paths for western industrialized countries, socialist countries and the non-socialist underdeveloped countries. Nonetheless, all forms converge on a model of considerable state control over medical care because of modernization, the emergence of a world economy, and the establishment of a world polity [2]. But against this general convergence theory, the professional power of physicians remains uneven, providing evidence of the intrinsic problems of the general model of convergence we see elsewhere.

*Professional power is the capacity of a highly educated group to (a) control the conditions of its occupational practice and reproduction; and (b) reshape other institutions, particularly of distribution, in its own collective interest [1].

†Corporatist representation is understood by Frenk and Donabedian [2, p. 28] as "a system of interest representation characterized by hierarchical and non-competitive occupational associations, which represent their members' interests through direct negotiations with the state".
However, Frenk and Donabedian find systemic roots for this variation [2, 28-29]. Physicians' greatest power is in societies where physicians are represented in a corporatist fashion and others are not, as in the U.S.A.t They are moderately powerful when both physicians and other groups are so organized, as in Sweden; moderately weak when the professional association is shared with other non-medical health care workers and no one else is organized in a corporate fashion, as in the U.S.S.R.; and very weak when others are corporatively organized and physicians are not, as in Mexico. This results in a neat two by two table (see Table 1).

According to these authors, this table clarifies the foundation for the professional power of physicians: it depends on the oganization of physicians themselves as well as the organization of the other groups with which they deal (see also Refs [3-5]). Paradoxically, although the bulk of Frenk and Donabedian's analysis of health care is based on state intervention, the effect of state power is left out of their account of professional power. 'Can't the state itself play a variable role, augmenting, restricting or redirecting professional power in medicine?' We argue that state power is central in the analysis of professional power. The elaboration of that thesis is the aim of the present essay.

\section{THEORETICAL FRAMEWORK}

One might improve Frenk and Donabedian's two by two table by introducing two major aspects. First, 
Table 1. Professional power and corporate organization cross-nationally

\begin{tabular}{llcc}
\hline & \multicolumn{2}{c}{ Representation of physicians } \\
\cline { 3 - 4 } Representation of other groups & Non-corp & Very powerful (U.S.A.) & Moderately weak (U.S.S.R.) \\
& Corp & Moderately powerful (Sweden) & Weak (Mexico) \\
\hline
\end{tabular}

Source: Frenk and Donabedian, 1987, p. 29.

introducing the consideration of state strength, and secondly, by incorporating the strategies followed by the state to deal with civil society.

\section{State power}

It is tempting to say that when the state controls more spheres of social life, the state is more powerful. But the capacity to control is not the same as the capacity to structure outcomes. There is a potential disjuncture between the resources of the state and the state's capacity to realize aims. Pierre Birnbaum argues, for instance, that strong states (characterized by high levels of institutionalization, differentiation and autonomy) are unable, as are weak states, to form corporatist systems [6]. Only where states are moderately strong can corporatist strategies be implemented. State resources, therefore, do not guarantee that the state can structure outcomes. Nor does state power, in terms either of its resources or its steering capacity, necessarily translate across sectors.

Capacities to intervene in foreign affairs and different capacities to intervene and structure outcomes in different areas of the domestic arena are not perfectly correlated [7]. Even the repressive power of the state and its commitment to organizing domestic activities is not always highly associated. For example, the Chilean 'program of libertarianism from above' was predicated on the basis of a 'small-state, strong-state' project in which the coercive power of the state grew as it tried to privatize formerly state functions [8]. Evans, Skocpol and Rueschemeyer recommend, therefore, that some "overall level of generalized capacity or 'state strength' cannot be used to explain the possibilities for successful state intervention" $[9$, p. 353]. They do argue, however, that certain basic capacities might structure opportunities for state actions. The scope of state intervention in its domestic affairs is one such basic capacity.

Although the state may not increase its ability to structure outcomes by extending control over more spheres of social and economic life, it can extend its ability to manipulate those resources that are available in that sector in accord with state policy. Thus, if we understand state power as control over resources and not the ability to realize outcomes, then state power can be understood as state interventionism.

States also vary significantly in this interventionist capacity. Some states organize medicine, the

*This analysis with regard the situations of Poland and the U.S.S.R. should be referred to the period between 1986 and 1989 , when this article was originally written. At that time in Poland, state intervention on health issues was ruled in the same way than other sectors of the Polish society by the direct control of a party-state. economy and civil society itself, while other states mainly provide the legal framework in which others organize health care, production and intergroup relations. State power as state interventionism thus shapes the opportunities for action by other groups, including physicians. And certainly it is the state which is the most significant organized actor with whom physicians deal, whether physicians are themselves organized or not.

We should like to argue that variations in state power structure the capacity of physicians to control their occupational practice and reproduction, and other social institutions which affect physicians' collective interest. But another major societal dimension also structures the professional power of physicians: the organization of civil society itself.

Frenk and Donabedian recognize the significance of civil society's organization for professional power when they introduce the question of its corporate organization [2]. But again, it is important that the state is missing from their model because the measure of state interventionism shapes the capacity for different forms of civil society's organization. It is not only important to consider the organization of civil society but also the relationship of the state to civil society when assessing professional power. The strength of physicians in the U.S.A. is not only contingent on their corporate organization, but also on the degree of state intervention. This is what most distinguishes Sweden from the United States, not the corporate organization of civil society. Sweden's corporate organization around labor has significance because it has been able to move the state to act on its behalf [10]; physicians' power in the U.S.A. has declined since 1970 partially because those without monopolies on knowledge or control over capital have been able to marshall state strength to limit professional power.

State power is greater when civil society is organized by it, rather than when struggles in civil society shape state policy. Where the state controls the organizations which are normally found in civil society, from manufacturing enterprises to trade unions and professional associations, we can say the state is most powerful, as in state socialist societies. Here, then, the power of physicians is moderately weak in the U.S.S.R. and Poland not because physicians are unorganized or because society is not organized in a corporate fashion, but because the state organizes them both.*

By introducing this notion of state power to explain variations in professional power, we reveal an anomaly that is otherwise invisible: the relationship between professional power and state power is curvilinear. The U.S.A./Sweden comparison suggests declining professional power with increased state power, but a comparison of Poland and Mexico 


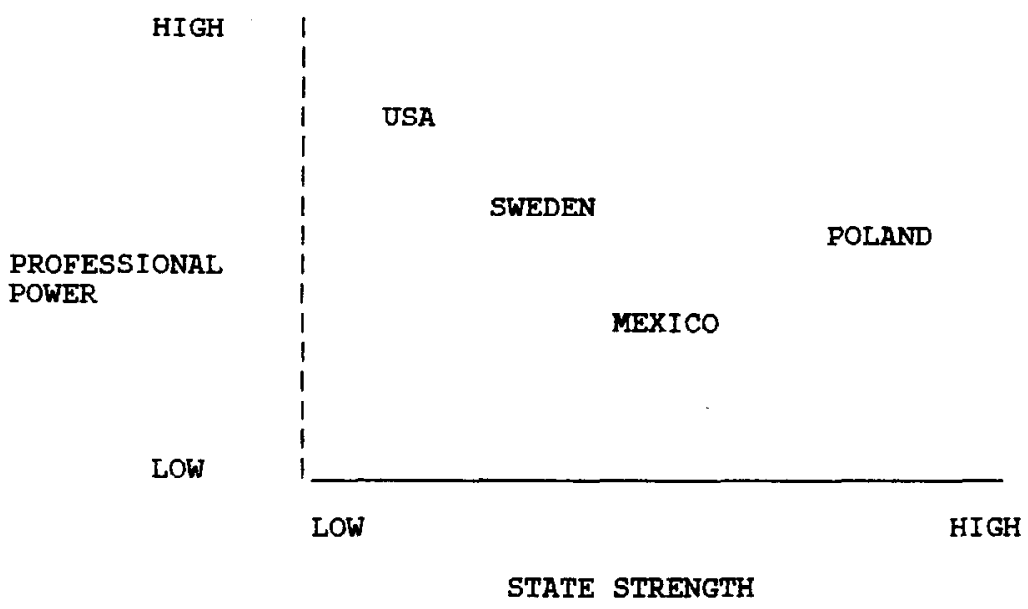

Fig. 1. Relationship between professional power and state power.

suggests increasing professional power with increased state power (see Fig. 1).

We should like to argue that differences in professional power are derived not only from the forms of organization of civil society per se, nor the general image of state strength based on the suppression of civil society, but also from the specific strategy followed by the state to deal with civil society. For example, in both Poland and Mexico, the state acts to organize civil society into its own coopted interest groups, but in Mexico, this organization emphasizes differentiation, dividing the society in different corporate sectors (entrepreneurs, peasant workers, state workers, and industrial workers). While in Poland the strategy followed is homogenization, through the direct control of all the sectors of society by the party-state. *

\section{State strategies}

In order to assess the effects of the strategies of the state we need a taxonomy of the ways in which the state can deal with civil society. Schmitter's taxonomy of corporatist intermediation is a good point of departure [11]. He argued that there were two types of corporatist intermediation: State corporatism and Societal corporatism.

1. State corporatism is characterized by a dominant state that organizes civil society by creating corporate bodies that are retained as its auxiliary and dependent organs.

2. By contrast, social corporatism is characterized by an autonomous organization of civil society, in

"The Mexican state has had 60 years of political 'peace' based on the oganization of the main political sectors in the Mexican society in corporate bodies. In this context, the Mexican medical profession is not organized corporatively and the sectors that are so organized, preclude its organization. Therefore, the power of the medical profession is low in Mexico due to the corporate organization of the Mexican society by the state. Whereas in the case of Poland, a soviet type state, the control of the profession by the state is done through its direct organization in state unions ruled by the party-state. which there is a balance between the power of the state and the civil society.

One more category should be added to the traditional categories of Schmitter to make his categories exhaustive. This is the non-corporative strategy to deal with civil society.

3. The non-corporative type may have two forms that have in common the lack of important corporate bodies in civil society.

The first form is the characteristic 'pluralist' society, where there is an autonomous organization of civil society but it is constituted by competitive noncorporative interest groups. In this, the legitimacy and functioning of the state is dependent on multiple coalitions of interest groups within a system of pluralist representation [12]. Alternatively, there is what Jessop calls state centralism, where the civil society is organized by the state around a single corporate body (i.e. communist party), and the legitimacy and functioning of the state is dependent on the same institution. The result of these additions is the theoretical framework presented in Table 2.

The framework depicted here is useful in identifying a number of relatively stable categories that reffect the relationship between professional and state power. It also enables us to trace historical movements across positions that may suggest future possibilities.

From the table we can derive two major divisions, namely, stable positions and transitional positions.

\section{STABLE POSITIONS}

There are four stable positions that correspond roughly to the dominant ways in which civil society and state relate in contemporary society. These are: Pluralism, Social Corporatism, State Corporatism and State Centralism.

\section{Pluralism}

Physicians gained power in the U.S.A. because of their ability to organize corporatively while the state played a limited role in organizing society and 
Table 2. Relationships between professional power, state strength and the organization of civil

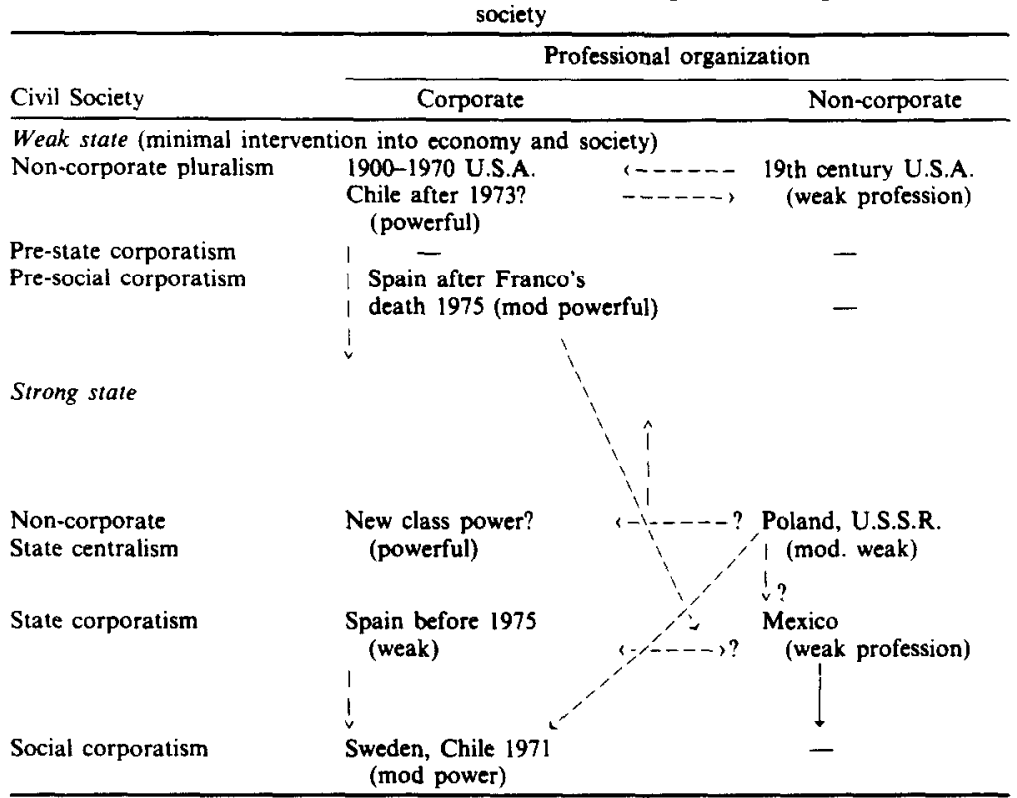

economy. Physicians' power remains great in comparison to other societies precisely because the state stands back, although in the present it appears that U.S. physicians are losing power to industrial corporations (e.g. hospital chains, health maintenance organizations, industry conglomerates, etc.), and other interest groups in society [13]. This may be evidence of a movement towards a new form of social organization. This movement is not represented on the table, however, as it does not involve a categorical shift in state/society relations. Instead, U.S. evolution signifies the intensification of its existing form where organizations based primarily on non-capital resources lose even more ground to those bodies based on capital. Professional organizations and trade unions both suffer in this transformation.

This movement is coupled in the health care area with an increasingly interventionist state. The prospective payment system, for example, is one of the biggest regulatory systems ever put in place by the state. Physicians might retain some of their professional leverage, however, by forming some kind of alliance with corporations, ${ }^{*}$ The interventionist role of the U.S. state is still comparatively restricted, especially in other areas of the economy. But given the pressures derived from the organization of new medical interest groups, capital and an increasingly interventionist state. U.S. physicians face a likely decline in their professional power $[2,12,15-19]$.

\section{Social corporatism}

Where there is no ready access to capital, other bodies in civil society gain power through the state,

*It is frequently found in the literature a reference to the increasing need of alliances between the physicians and administrators to control costs and maintain the quality of care in the U.S. [14]. This is an example of the recognition of the weakening position of physicians vis $a$ vis other groups in American Society. at least until the state is already a dominant influence in economy and society. If those without independent access to capital or state power manage to organize themselves independently in civil society, as through trade unions, they can gain considerable power and offset the corporate organization of professionals through society's influence over the state. Sweden represents this possibility, but so would Chile in 1971 $[20,21]$.

Swedish civil society's corporate organization was established through the state's mediation. This required a more interventionist state, but our model makes this an historical outcome, not an evolutionary one. Although there is a tendency over time, as Frenk and Donabedian emphasize, for the state to become more interventionist, state power can reorganize itself in special historical conjunctures with terrific consequence for the character of professional power.

The Thatcher/Reagan privatization scheme emerges as one alternative reversing the state intervention. In that case, Britain could return to the weak state model presented above. The case of the Chilean society after Pinochet's coup d'etat, is another example of a reversal in state interventionism. Although the state certainly increased its coercive prerogative, it transformed the national health service of Chile into a U.S.-like private health care system in a matter of years [21, 22].

\section{State corporatism}

Once the state does intervene, the range of possibilities for professional power grows considerably, as is presented in Table 2. Where the civil society's autonomy is restricted by the state, both professionals and other social groups have limited possibilities for power. But the way in which the state organizes civil society has great consequences for the possibilities for professional power. State organization of civil society is synonymous with cooptation of voluntary associations. This occurs both in state 
socialist societies and in state capitalist societies represented by Mexico. Ironically, however, Mexican state power is more effective in repressing professional power because while it coopts society, it also differentiates it by separating potentially dangerous interest groups in different corporations (entrepreneurs, peasant workers, state workers, and industrial workers), reducing the possibility for the solidary organization of society against the state [23]. The medical profession in Mexico is weak not only because its interests are not represented by a corporation, but because the medical profession is inserted in different corporate bodies controlled by the state that paradoxically preclude the corporative organization of the medical profession [24].*

\section{State centralism}

As was arguid above, the cooptation of voluntary associations is a characteristic of state organization of civil society. Cooptation also occurs in state centralist societies, but in this case cooptation is accompanied by homogenization. This is most apparent in socialist countries where the authorities coopt different interest groups into one broad organization (the party) or its extensions (official trade unions). Despite the appearance of greater state power, this combination is potentially unstable. Recent developments in Poland and the Soviet Union suggest that nations in this position are likely to move in the direction of state corporatism (the Mexican option) [25], or of the other two alternative futures suggested by the table: (a) increased control by professionals over the state resulting in unparalleled class power by professionals (a technocracy) $[26,27]$; or (b) solidary organization by civil society against the state, where all sectors of society become organized in their struggle against state organization of society (societal corporatism).

It seems much less likely that professionals in these countries could move to the new class option precisely because they are themselves lacking a common class or even professional organization and consciousness to establish this rule. The Mexican option is a considerably more stable form of state domination over civil society and professionals in particular, given its capacity to fragment professional interests. However, the experience of Solidarity in 1980-81 suggests that the social corporatist option is most appealing to 'society', as the Solidarity movement organized various sectors of the Polish civil society against the state [28]. The imposition of martial law on 31 December 1981 suggests that a social corporatism may well be impossible from the authorities' point of view. Even with solidarity's electoral victory in 1989 , the compatibility between economic recovery and societal corporatism is most uncertain given the austerity reconstruction will require. Thus, the Mexican option, with even less professional power for physicians, may well be the most likely future for state centralist societies. These various options are depicted in Table 2.

* Physicians do work and are represented within different sectors of the Mexican political system, the labor sector, the state bureaucracy sector, and the ministry of health, all of them organized in a corporative fashion.

\section{TRANSITIONAL POSITIONS}

Transitional positions are those which are unstable and contradictory in terms of the expected relationship between the form of state intervention and the organization of civil society.

For example these positions may be contradictory when they present simultaneously retractions of state power and of the corporate organization of society, which are bound to conflict and struggle for dominance. They are transitional since stability cannot be achieved unless compatible forms of organization of civil society and state strategies are combined, in order to balance the power of groups with and without monopolies on capital or special knowledge and skills. It is our contention that nation states in these transitional positions eventually will adopt one of the four major stable positions.

In Spain, for example, the fall of Franco caused just such a transitional period. In the 1960's and 1970 's Spain was the prototype of state corporatism. In fact, up to 1975 even though the medical profession in Spain was corporatively organized, it was as weak and politically dominated as the medical profession in Mexico [29]. Clearly, therefore, state power is far more important to deciding professional power than is the group's own corporate organization. However, the group organization is very important in transition periods.

After Franco's death in 1975, the political system in Spain has undergone a number of transformations that have led to a pluralistic democratic political regime, restricting the state's power to organize civil society. These changes have situated Spain in a transitional position that we have called pre-societal corporatism. In this new situation the medical profession emerged from the dictatorship as a strong corporate body and in the first years of democratic government the medical profession continuously confronted the state in its attempt to secure an even more powerful position [30]. However, since 1986 the medical profession has moved away from confrontational policies to a more accomodational strategy, based on negotiation with the state. The future of professional power in Spain depends very much, however, on the way in which the state resumes its intervention, which in turn depends on how the rest of civil society manages to organize itself.

This brief summary of the multiple changes in Spanish society shows the relevance of the theoretical framework in assessing movements and changes in state strength, civil society and the organization of the medical profession. The Spanish medical profession is in a transitional stage precisely because Spain itself is undergong a transformation characterized by the return of an autonomous civil society as the state has withdrawn [31].

\section{EPILOGUE}

By considering both state power and the strategies used by the state to control civil society, it is possible to differentiate more clearly the historical patterns of development of the medical profession in different nation states. This is particularly useful to shed light on the different levels of power of the medical 
profession across nations, as well as to illustrate how its power depends on the outcome of conflicts and struggles between states and societies and among the various groups within civil society.

In a forthcoming paper, we will assess the utility of this perspective on the struggle between state power and professional power illustrated through a detailed comparative historical analysis of the constitution of physicians in Mexico and Poland in the twentieth century. We will illustrate the common coopting mechanisms in Mexico and Poland, the dangers for state power of a non-differentiated cooptation in Poland and the advantages of this differentiation in Mexico. Finally, we will suggest the likely futures of professional power in each socicty.

In this paper, however, we hope to have suggested the utility of thinking about professional power as a historical project whose directions depend on the relationship between the state and the civil society in which physicians act. Although this model was built partly on the comparison of Polish and Mexican physicians, its heuristic utility ought to extend to physicians in the variety of societies found in the twentieth century.

Acknowledgements-Previous versions of this paper have been presented in 1988 at the National Institute of Public Health of Mexico, the Annual Meeting of the American Sociological Association and in the Center for Research on Social Organization of The University of Michigan. The work of Dr Duran was developed under the sponsorship of the internal medicine department of the University of Michigan Medical Center. We wish to thank especially Julio Frenk, Mayer Zald and Gayle Ness for their comments on previous versions of this paper. We assume full responsibility for the arguments and views expressed in this contribution.

\section{REFERENCES}

1. Kennedy M. and Sadkowski K. Constraints on professional power in Soviet-type society: Insights from the Solidarity period in Poland. In: Professions and the State: The organization of Professional Work in the Soviet Union and Eastern Europe. Temple University Press, Philadelphia, PA. In press.

2. Frenk J. and Donabedian A. State intervention in medical care: types, trends and variables. Hith Policy Planning 2, 17-31, 1987.

3. Starr P. The Social Transformation of American Medicine. Basic Books, New York, 1982.

4. Larson M. S. The Rise of Professionalism. University of California Press, Berkeley, 1977.

5. Johnson T. J. Professions and Power. McMillan, London, 1972.

6. Birnbaum P. States and Collective Action: The European Experience. Cambridge University Press, Cambridge, 1988.

7. Skocpol T. Strategies of analysis in current research. In Bringing the State Back In (Edited by Evans P., Rueschemeyer D. and Skocpol T.). Cambridge University Press, Cambridge, 1985 .

8. Stepan A. State power and the strength of civil society in the southern cone of Latin America. In Bringing the State Back In (Edited by Evans P., Rueschemeyer D. and Skocpol T.). Cambridge University Press, Cambridge 1985 .

9. Evans P. B., Rueschemeyer D. and Skocpol T. On the road toward a more adequate understanding of the state. Bringing the State Back In (Edited by Evans P., Rueschemeyer D. and Skocpol T.). Cambridge University Press, Cambridge 1985.

10. Korpi W. The Working Class in Welfare Capitalism: Work, Unions and Politics in Sweden. Routledge \& Kegan Paul, London. 1978.

11. Schmitter P. C. Still the century of corporatism? In: Trends Towards Corporatist Intermediation. Contemporary Political Sociology, Vol. I (Edited by Schmitter P. C. and Lehmbruch G.). SAGE publications, Beverly Hills, CA, 1979.

12. Jessop B. Corporatism, parliamentarism and social democracy. In Trends Towards Corporatist Intermediation. Contemporary Political Sociology, Vol. 1. (Edited by Schmitter P. C. and Lehmbruch G.). SAGE publications, Beverly Hills, CA, 1979.

13. McKinlay J. B. and Stoeckle J. D. Corporatization and the social transformation of doctoring. Int. J. Hith Services 18, 191-205, 1988.

14. Greifinger R. B. and Bluestone M. S. Building physician alliances for cost-containment. Hlth Care Management Rev. 11, 63 72, 1986.

15. Schwarz $H$. Florida says pharmacists may prescribe drugs. New York Times 12 April, 1986.

16. Relman A. The new medical industrial complex. N. Engl. J. Med. 303, 963-970, 1980.

17. Relman A. The future of medical practice. Hlth Affairs 2, 5-19, 1983.

18. American Medical Association. Effects of competition in medicine. JAMA 249, 1864-1868, 1983.

19. Berrien $R$. What future for primary care private practice? N. Engl. J. Med. 316, 334-337, 1987.

20. Roemer M. I. Health Care Systems in World Perspective. Health Administration Press, Ann Arbor, 1976.

21. Faber C. Health in Chile: Running on empty. Links, 1988.

22. Levy D. C. Higher Education and the State in Latin America: Private Challenges to Public Dominance. University of Chicago Press, Chicago, IL, 1986.

23. Leal J. F. Intento de renovacion del corporativismo Mexicano. La cultura en Mexico, suplemento de Siempre, 14 November 1973.

24. Cleaves P. S. Professions and the State: The Mexican Case. The University of Arizona Press, Tucson, AZ, 1987.

25. Ost D. Towards a corporatist solution in Eastern Europe: The case of Poland. East. Eur. Politics Soc. 3, 152-174, 1989.

26. Szelenyi I. The intelligentsia in the class structure of state socialist societies. Marxist Inquiries, pp. 287-326 (Edited by Burawoy N. and Skocpol T.). University of Chicago Press, Chicago, 1982.

27. Gouldner A. The Future of Intellectuals and the Rise of the New Class. Seabury, New York, 1979.

28. Kennedy M. Professionals, Power and Solidarity in Poland: A Critical Sociology of Soviet-Type Society. Cambridge University Press, Cambridge, In press.

29. Rodriguez J. A. and de Miguel J. M. The political dynamics of physician manpower policy: The case of Spain. Int. Conf. the Political Dynamics of Physician Manpower Policy, London, 1988.

30. Rodriguez L. A. Estructura de la profesion medica Espanola. Revista Espanola de Investigaciones Sociologicas 39, 48-62, 1987.

31. Perez V. El Retorno de la Sociedad Civil. Instituto de Estudios Economicos, Madrid, Spain, 1987. 